Original Paper

\title{
Penggunaan Bahan Ajar IPA berbasis Pendekatan SAVI (Somatic, Auditory, Visual, Intellectual) untuk Meningkatkan Hasil Belajar Peserta Didik
}

\author{
Fitran Sari $1^{*}$ \\ ${ }^{1}$ Sekolah Menengah Pertama Negeri 3 Mataram, Indonesia
}

*Corresponding Author:

Fitran Sari, Sekolah

Menengah Pertama

Negeri 3 Mataram,

Indonesia.

Email:

fitransari@yahoo.com

\begin{abstract}
Abstrak: Tujuan penelitian ini meningkatan hasil belajar peserta didik menggunakan pendekatan berbasis SAVI (somatic, Auditory, Visual, Intellectual) pada kelas VII-1 semester genap tahun pelajaran 2016/2017 materi organisasi tingkat kehidupan. Jenis penelitian ini adalah Penelitian Tindakan Kelas model Kemmis dan Tanggart terdiri 3 siklus. Adapun tahapan setiap siklus terdiri dari perencanaan (planning), Tindakan (Action), Observasi (observation) dan refleksi (reflection). Subyek penelitian adalah peserta didik kelas VII-1 berjumlah 26 orang. Adapun hasil penelitian Tindakan Kelas menunjukkan peningkatan setiap siklus. Siklus I memperoleh rata-rata skor peserta didik 25, aktivitas pendidik $77 \%$ ketuntasan secara klasikal $0 \%$, siklus II rata-rata skor 51, aktivitas pendidik $86 \%$, ketuntasan secara klasikal 41,6\%, siklus III rata-rata skor peserta didik 72 , aktivitas pendidik $91 \%$ dan kekuntasan secara klasikal 71\%. Dengan demikian dapat simpulkan bahwa penggunaan bahan ajar IPA berbasis pendekatan SAVI dapat meningkatkan hasil belajar peserta didik.
\end{abstract}

Kata kunci: Bahan ajar; SAVI; Hasil belajar

\section{Pendahuluan}

Proses pembelajaran pada satuan pendidikan sebaiknya diselenggarakan secara interaktif, inspiratif, menyenangkan, menantang, memotivasi siswa untuk berpartisipasi aktif serta memberikan ruang yang cukup bagi prakarsa, kreativitas, dan kemandirian sesuai dengan bakat, minat dan perkembangan fisik dan psikologis siswa (Winanto \& Makahube, 2016). Terselenggaranya proses pembelajaran tersebut memerlukan guru yang kreatif dan inovatif, guru yang selalu melakukan perubahan dan pembaharuan dan mau mencoba sesuatu yang baru (Zein, 2016).

Perubahan paradigma pengajaran dan pembelajaran amat bergantung pada pemahaman para guru tentang dasar dan teori keguruan yang dianut, tergantung cara pandang (point of vew) dan pola pikir (mindset) tentang peran dan kompetensi profesional guru dalam proses pembelajaran di sekolah (Abdul Rasid \& Hasmah, 2013). Guru yang profesional dapat melibatkan secara dominan siswa (student centered) dalam proses pembelajaran sehingga tidak lagi berpusat pada guru (teacher centered), peran guru adalah sebagai fasilitator (Zein, 2016).

Guru profesional perlu memahami karakteristik siswa salah satunya adalah gaya belajar untuk mencapai prestasi optimal (Widayanti, 2013). Siswa memiliki gaya belajar yang berbeda dan unik untuk menyerap pengetahuan (Widayanti, 2013). Gaya belajar adalah kunci untuk mengembangkan kinerja dalam pekerjaan, di sekolah dan situasi-situasi antar pribadi (Marpaung, 2016). Adapun gaya belajar yang dimiliki siswa adalah gaya 
kinestetik, gaya belajar auditorial dan gaya belajar visual.

Perbedaaan individu dalam belajar seperti memahami gaya belajar siswa merupakan salah satu cara mengembangkan kreativitas siswa. Guru harus menghargai keunikan pribadi dan potensi setiap subyek didik dan tidak perlu selalu menuntut dilakukan hal-hal yang sama (Khoiruddin, 2017).

SAVI (Somatic, Auditory, visual, Intellectual) merupakan pendekatan belajar yang menggabungkan gerakan fisik dengan aktivitas intelektual dan penggunaan semua indera dapat memiliki efek mendalam pada pembelajaran (Idaramatasia, 2015). Pembelajaran SAVI menganut aliran kognitif modern yang menyatakan belajar yang paling baik adalah melibatkan emosi, seluruh tubuh, semua indera dan segenap kedalaman serta keluasan pribadi, menghormati gaya belajar individu dengan menyadari bahwa orang belajar dengan cara-cara berbeda (stefany, 2016).

Gaya belajar yang berbeda dan unik yang dimiliki oleh siswa menjadi tolak ukur untuk merencanakan kegiatan pembelajaran yang baik. Perencanaan kegiatan pembelajaran yang baik perlu memperhatikan keterkaitan antara KI, KD, tujuan, indikator, bahan ajar, media, model, metode, pendekatan, sumber, alat evaluasi serta gaya belajar siswa.

Berdasarkan hasil belajar siswa pada semester 1 pada KD 3.2 dan 3.3, tingkat ketuntasan sesuai dengan KKM yang telah ditetapkan masih tergolong rendah. Hasil ulangan pertama dari 26 siswa 7 orang yang tuntas, ulangan yang ketiga 12 yang tuntas. Sehinggga setiap KD memerlukan pengajaran ulang. Untuk lebih jelas disajikan pada Tabel 1.

Tabel 1. Jumlah siswa yang tuntas sesuai KD.

\begin{tabular}{|c|c|c|c|}
\hline No & KD & Rata -rata nilai & $\begin{array}{l}\text { Jumlah siswa } \\
\text { yang tuntas }\end{array}$ \\
\hline 1 & $\begin{array}{l}\text { 3.2 Memahami konsep campuran dan zat tunggal (unsur } \\
\text { dan senyawa), sifat fisika dan kimia, perubahan fisika } \\
\text { dan kimia dalam kehidupan sehari-hari }\end{array}$ & 52 & 7 \\
\hline 2 & $\begin{array}{l}\text { 3.3 Memahami konsep energi, berbagai sumber energi, dan } \\
\text { perubahan bentuk energi dalam kehidupan sehari-hari } \\
\text { termasuk fotosintesis }\end{array}$ & 61 & 12 \\
\hline
\end{tabular}

Hasil analisis hasil belajar dan gaya belajar, maka memandang perlu menggunakan pendekatan yang sesuai dengan gaya belajar siswa. Kegiatan pembelajaran yang dipergunakan oleh guru selama ini belum mengoptimalkan dan mengakomodir cara belajar siswa. Hal ini dapat terlihat dari hasil observasi siswa selama kegiatan pembelajaran. Siswa memiliki gaya belajar yang berbeda-beda seperti gaya belajar visual yaitu menyukai mengamati, audio suka berbicara atau mendengar atau menggunakan aktivitas tubuh seperti kegiatan eksperimen, atau menggambar.
Berdasarkan latar belakang tersebut maka penulis melakukan Penelitian Tindakan Kelas untuk mengatasi rendahnya nilai hasil belajar siswa di SMPN 3 Mataram dengan judul "Penggunaan Bahan Ajar IPA Berbasis Pendekatan SAVI (somatic, Auditory, Visual, Intellectual) untuk Meningkatkan Hasil belajar Siswa".

\section{Metode}

A. Objek Tindakan

Objek tindakan dalam penelitian ini adalah usaha seorang pendidik dalam meningkatkan Hasil Belajar peserta didik 
melalui pembelajaran dengan pendekatan SAVI (Somatic, Auditory, Visual, Intellectual).

B. Setting, Lokasi, dan SubjekPenelitian

Penelitian ini menggunakan setting penelitian Tindakan Kelas (PTK-Classroom Bused Action Research). Penelitian ini dilakukan di SMP Negeri 3 Mataram yang beralamat di Jln. Niaga I No 39 Ampenan. Subyek penelitian adalah siswa kelas VII-1 berjumlah 26 orang terdiri dari laki-laki 15 dan perempuan terdiri dari 11 orang. Penelitian dilaksanakan pada semester genap tahun pelajaran 2016/2017 materi Organisasi Kehidupan.

Dalam penelitian ini pendidik juga sekaligus bertindak sebagai peneliti. Model rancangan penelitian ini mengacu pada model yang dikemukakan oleh Kemmis dan Tanggart (1998) dengan tiga siklus. Masing-masing siklus terdiri dari empat tahap yaitu: 1) Tahap penyusunan rencana tindakan; 2) Tahap pelaksanaan tindakan; 3) Tahap observasi, dan 4) Tahap refleksi.

Kemmis dan Tanggart memperkenal model rancangan penelitian dengan siklus diulang-ulang terus menerus sampai masalah yang diteliti dapat dipecahkan atau diatasi dengan baik. Model Kemmis dan Tanggart ini dapat digambarkan dalam bentuk spriral.

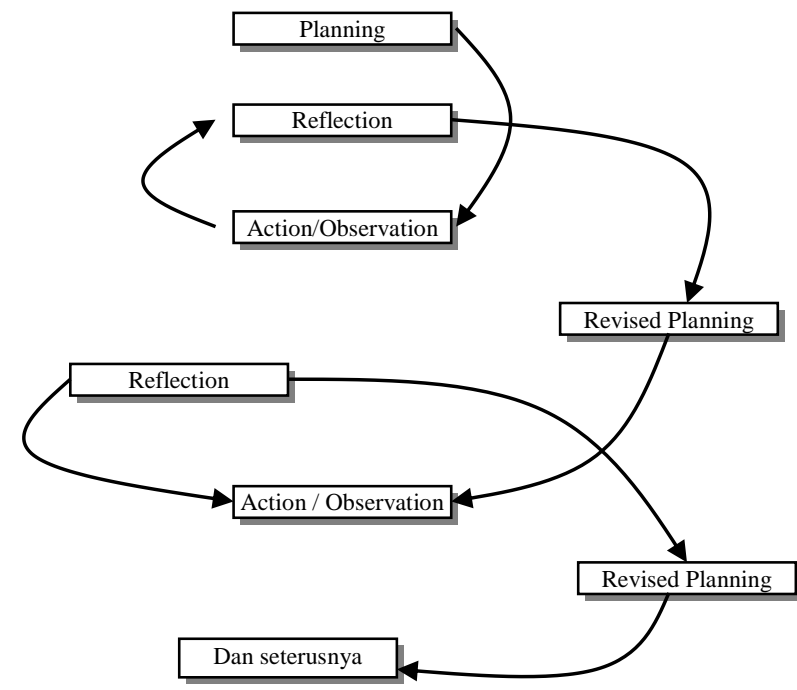

Gambar 1. Siklus dalam PTK menurut Kemmis dan Taggart
C. Metode Pengumpulan Data

Pengumpulan data hasil penelitian adalah: 1) Angket keterlaksanaan penggunaan bahan ajar berbasis pendekatan SAVI oleh pendidik; 2) Catatan hasil observasi selama kegiatan pembelajaran baik kegiatan peserta didik maupun pendidik; 3) Instrumen hasil belajar peserta didik; dan 4) Dokumentasi.

D. Metode Analisis Data

Data yang diperoleh dari hasil angket aktivitas pendidik menggunakan bahan ajar berbasis pendekatan SAVI dihitung menggunakan rumus :

Nilai $=\frac{\text { Jumlah skor yang diperoleh }}{\text { jumlah skor seluruhnya }}$

Kriteria aktivitas pendidik mennggunakan bahan ajar berbasis pendekatan SAVI disajikan pada Tabel 2.

Tabel 2 : Kriteria aktivitas pendidik

\begin{tabular}{lll}
\hline No & Rentang nilai & Kriteria \\
\hline 1 & $80-100$ & Sangat Baik \\
2 & $66-79$ & Baik \\
3 & $56-65$ & Cukup \\
4 & $40-55$ & Kurang \\
5 & $30-39$ & Gagal \\
\hline
\end{tabular}

Data yang diperoleh dari instrumen hasil belajar peserta didik dihitung menggunakan rumus sebagai berikut:

Nilai $=\frac{\text { Jumlah skor yang diperoleh }}{\text { jumlah skor seluruhnya }}$

E. Data dan sumber data

Data penelitian terdiri atas: 1) Data angket aktivitas keterlaksanan bahan ajar berbasis pendekatan SAVI oleh pendidik; 2) Data instrumen hasil belajar peserta didik. Sumber data adalah: 1) Sumber data penelitian adalah peserta didik kelas VII-2 sebagai subyek penelitian; 2) Pendidik sebagai peneliti 
pengguna bahan ajar berbasis pendekatan SAVI.

F. Indikator keberhasilan

Indikator keberhasilan penelitian ini adalah: 1) Hasil belajar dikatakan meningkat apabila rata-rata nilai yang diperoleh $\geq 70$ dan ketuntasan peserta didik secara klasikal mencapai $70 \%$; 2) Keterlaksanaan bahan ajar berbasis pendekatan SAVI dikatakan berhasil jika langkah-langkah yang dilakukan pendidik berada pada kriteria amat baik.

\section{G. Cara Pengambilan Kesimpulan}

Untuk mengambil kesimpulan dalam penelitian ini menggunakan analisis hasil berdasarkan temuan pada setiap siklus. Dari perkembangan setiap siklus maka dapat diambil kesimpulan dari hasil penelitian ini.

\section{Hasil dan Pembahasan}

Gambaran secara umum dalam penelitian ini adalah sebagai berikut: Pada siklus I pada umumnya peserta didik belum berperan aktif dalam proses pembelajaran.
Hal ini disebabkan karena peserta didik belum terbiasa menggunakan alat-alat laboratorium seperti miskroskop, dan juga kesulitan membaca atau melapalkan kata-kata latin yang menyusun sel, walau demikian keingintahuan peserta didik untuk penggunakan mikroskop sudah muncul, namun pada siklus II sudah ada peningkatan keterampilan penggunakan mikroskop begitu pula dengan alat-alat dan bahan praktikum yang lainnya. Siklus III peserta didik sudah mahir menggunakan mikroskop serta motivasi belajar cukup tinggi.

Adapun nilai rata-rata yang diperoleh dari evaluasi hasil belajar sebagai berikut: pada siklus I rata-rata nilai yang diperoleh 25, pada siklus II 51 dan siklus III nilai rata-rata yang diperoleh 72. Siklus tidak dilanjutkan lagi karena apa yang dirumuskan dalam penelitian sudah terjawab, yaitu bahwa prestasi belajar peserta didik sudah mengalami peningkatan dan berada pada kriteria baik dengan tingkat ketuntasan secara klasikal 71\%.

Data penelitian pada Siklus I, II, dan III ditunjukkan seperti Tabel 3.

Tabel 3. Data Hasil Panalitian pada Siklus I, II, dan III.

\begin{tabular}{clccc}
\hline \multirow{2}{*}{ NO NAMA } & & \multicolumn{3}{c}{ Nilai Setiap Siklus } \\
\cline { 3 - 5 } & & Siklus I & Siklus II & Siklus III \\
\hline 1 & Adam Mustafa & 10 & 12 & 43 \\
2 & Agung Bagus Saputra & 45 & 82 & 71 \\
3 & Agus Permadi & 0 & 0 & 36 \\
4 & Andhika Restu Putra & 25 & 76 & 79 \\
5 & Annisa Rahma Diyanti & 58 & 100 & 100 \\
6 & Cintyia Putri Aprilia & 45 & 53 & 71 \\
7 & Dedi Permadi & 3 & 6 & 36 \\
8 & Hesti Meilani & 50 & 76 & 86 \\
9 & Imam Azhari & 25 & 71 & 79 \\
10 & Khaela Nievana Herman & 8 & 41 & 36 \\
11 & Ki Agus Diky Irawan & 5 & 12 & 57 \\
12 & L. M. Zemafatahillah & 10 & 24 & 71 \\
13 & Mardiana Safitri & 0 & 53 & 100 \\
14 & Maulana Rizky Hidayat & 58 & 100 & 100 \\
15 & Maulidina Soleha & 0 & 71 & 100 \\
16 & Nabila Optyawanda & 58 & 82 & 100 \\
17 & Nurhidayah & 25 & 71 & 71 \\
18 & Putri Jayanti & 8 & 35 & 36 \\
19 & Rizaldi Muhammad Nur & 58 & 29 & 79 \\
\hline
\end{tabular}




\begin{tabular}{clrrc}
\hline \multirow{2}{*}{ NO } & \multirow{2}{*}{ NAMA } & \multicolumn{3}{c}{ Nilai Setiap Siklus } \\
\cline { 3 - 5 } & & Siklus I & Siklus II & Siklus III \\
\hline 20 & Sandy Prayoga P. S & 10 & 24 & 64 \\
21 & Septi Ambar Wati & 0 & 41 & 79 \\
22 & Wahyu Jodi Pratama & 10 & 41 & 86 \\
23 & Yuyun Kurnia Iskandar & 48 & 76 & 71 \\
24 & Zaina Karima Alkaf & 55 & 59 & 71 \\
Jumlah & & 610 & 1235 & 1721 \\
Rata-Rata & 25 & 51 & 72 \\
\hline
\end{tabular}

\section{Siklus I}

Berdasarkan data pada Tabel 3 rata-rata nilai peserta didik 25. Ketuntasan secara klasikal tidak ada peserta didik yang tuntas. Merujuk pada kriteria yang telah dietentukan, maka belum memenuhi indikator keberhasilan.

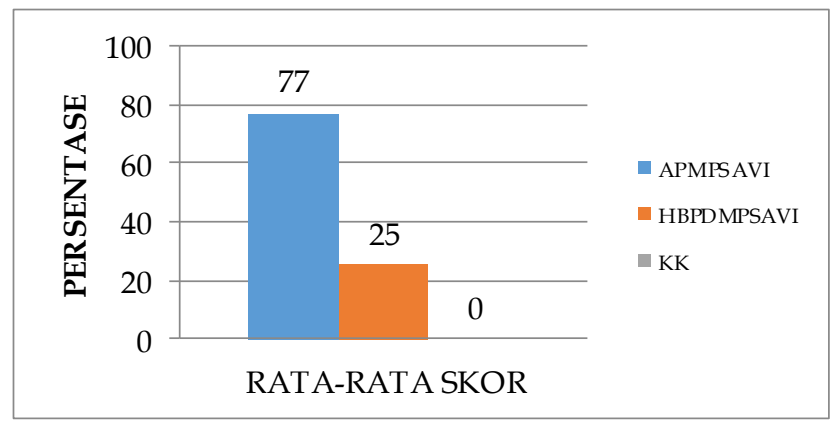

Keterangan

APMPSAVI = Aktivitas Pendidik Menggunakan pendekakatan SAVI.

HBPDMPSA=Hasil Belajar Peserta Didik Menggunakan Pendekatan SAVI

$\mathrm{KK}=$ Ketuntasan Klasikal

Berdasarkan hasil observasi yang diperoleh pada siklus I, diperoleh data sebagai berikut:

1) Pada tahap pendahuluan tidak dilaksanakan sesuai dengan alokasi yang telah disediakan. Begitu halnya manfaat mempelajari materi tidak disampaikan kepada peserta didik

2) Tahap penyampaian peserta didik kesulitan menggunakan mikroskop karena sebagian besar peserta didik belum terbiasa menggunakan mikroskop. Sehingga perlu dilatih khusus dalam penggunaan mikroskop.
3) Peserta didik kesulitan menggambar preparat yang telah dibuat karena tidak ada contoh gambar sel yang disajikan oleh pendidik pada LKPD.

4) Beberapa peserta didik dalam kegiatan pengamatan tidak melaksanakan tugas dengan baik, sehingga pendidik mengigatkan agar membantu teman untuk mengerjakan tugas (kerja sama antara anggota kelompok masih perlu ditingkatkan).

5) Instrumen evaluasi yang disusun perlu disederhanakan

\section{Siklus II}

Berdasarkan Tabel 3, nilai rata-rata yang diperoleh peserta didik 51 dengan ketuntasan secara klasikal 10 orang yaitu 41,6\%. Namun merujuk pada kriteria yang ditentukna maka belum memenuhi indikator keberhasilan.

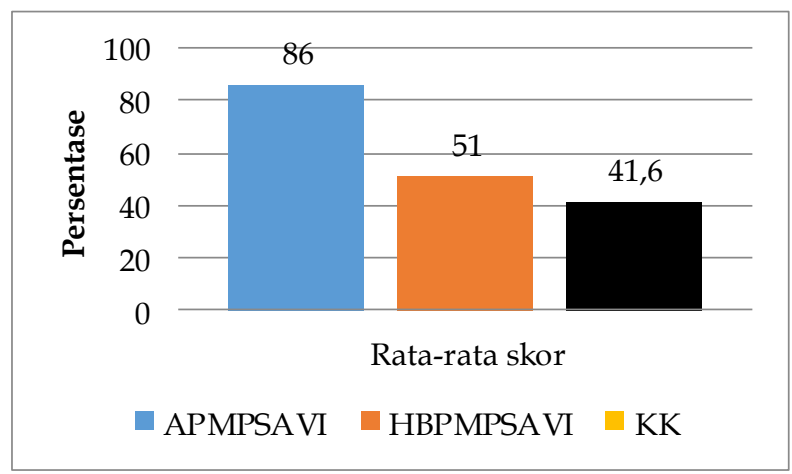

Keterangan

APMPSAVI = Aktivitas Pendidik Menggunakan pendekakatan SAVI

HBPDMPSA $=$ Hasil Belajar Peserta Didik

Menggunakan Pendekatan SAVI

$\mathrm{KK}=$ Ketuntasan Klasikal 
Berdasarkan hasil observasi yang diperoleh pada siklus II, diperoleh data sebagai berikut:

1) Penggunaan mikroskop pada umumnya oleh peserta didik sudah benar. Pendidik tidak dominan lagi dalam kegiatan pembelajaran. Peserta didik secara bergantian mengamati serta menggambarkan preparat yang telah dibuat.

2) Kegiatan menggambar hasil pengamatan sudah lebih cepat dibandingkan dengan siklus I, Walaupun demikian mash perlu bimbingan untuk memfasilitasi keterbatasan pengetahuan peserta didik untuk menentukan bagian-bagian jaringan yang menyusun daun.

3) Masih ada peserta didik yang belum mampu berkosentrasi dalam kegiatan pengamatan. Ada anggota kelompok karena rasa ingin tahu berkeliling menuju ke kelompok lain untuk mengamati preparat, sehingga mengabaikan kelompoknya sendiri

4) Terlihat pendidik mengarahkan peserta didik yang konsentrasi buyar untuk kembali bekerjasama dengan kelompoknya.

5) Jika dibandingkan dengan kegiatan pembelajaran pada siklus I maka kegiatan pembelajaran terjadi peningkatan aktivitas peserta didik serta antusias dalam belajar pada siklus II

6) Untuk tidak didominasi oleh satu orang peserta didik dalam mengkomunikasikan hasil pengamatan sebaiknya peserta didik diminta untuk mengkomunikasikan secara bersama-sama dengan membagi tugas.

\section{Siklus III}

Bredasarkan Tabel 3, rata-rata nilai peserta didik 72 dengan nilai ketuntasan secara klasikal 71\%. Merujuk pada kriteria yang telah ditentukan maka telah mencapai indikator keberhasilan yaitu nilai rata-rata kelas peserta 70 dan ketuntasan secara klasikal 70\%.

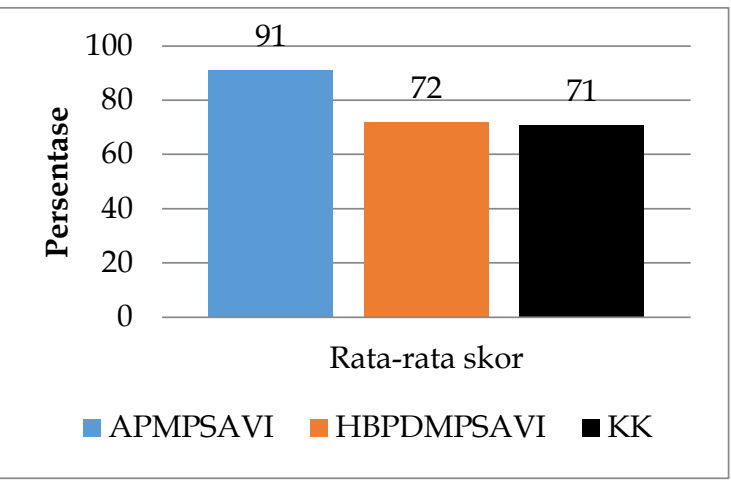

Keterangan

APMPSAVI $=$ Aktivitas Peserta didik

Menggunakan pendekakatan SAVI

HBPDMPSA $=$ Hasil Belajar Peserta Didik

Menggunakan Pendekatan SAVI

$\mathrm{KK}=$ Ketuntasan Klasikal

Berdasarkan hasil observasi yang diperoleh pada siklus III, diperoleh data sebagai berikut:

1) Semua tahapan pada langkah-langkah pembelajaran telah terlaksana sesuai dengan yang direncanakan

2) Peserta didik antusias untuk melakukan pengamatan, berdiskusi maupun mengkomunikasikan hasil pengamatan

3) Perlu bimbingan kepada peserta didik yang kurang berkonsentrasi dalam belajar.

4) Peserta didik sebaiknya dibiasakan mengkomunikan hasil pengamatan atau diberi pertanyaan sehingga peserta didik berusaha mencari jawaban atau membuat pertanyaan sehingga berkomunikasi menjadi salah satu karakter pembiasaan dalam kegiatan pembelajaran.

Hasil observasi oleh observer selama kegiatan pembelajaran, rasa ingin tahu peserta didik meningkat dari setiap Siklus, LKPD berbasis pendekatan SAVI terbukti mampu memotivasi peserta didik dalam kegiatan pembelajaran. Hal ini mendukung hasil penelitian yang telah dilakukan (Munandar, Yusrizal, \& Mustanir, 2015) menyatakan bahwa peserta didik merasa senang apabila LKPD digunakan saat pembelajaran di kelas karena membuat mereka mengerti cara merancang percobaan IPA dengan langkah 
percobaan yang sederhana, mudah dipahami, dan mudah dilaksanakan.

Hasil aktivitas pendidik terhadap keterlaksanaan RPP berbasis pendekatan SAVI sebanyak 3 siklus. Menurut hasil observasinya, pelaksanaan pembelajaran dengan RPP berbasis pendekatan SAVI layak digunakan dalam: menumbuhkan rasa ingin tahu peserta didik, menumbuhkan sikap spiritual dan sikap sosial, mengidentifikasi masalah melalui kegiatan pengamatan, menceritakan atau mengemukakan pendapat, melakukan percobaan, menggambar, menganalisa data, dan mengukur pemahaman peserta didik, mengkomunikasikan hasil, dan menyimpulkan.

Instrument evaluasi yang disusun bertujuan untuk mengukur tingkat pemahaman peserta didik terhadap materi pelajaran yang telah dipelajari. Adapun langkah-langkah penyusunan instrumen evaluasi yaitu: mengidentifikasi indikatorindikator, membuat instrumen, menentukan kunci jawaban dan pedoman penskoran selanjutnya melaksanakan evaluasi, berdasarkan indikator dan tuntutan intelektual.

Instrumen Evaluasi yang digunakan pada siklus I, II, dan III jumlah no soal disesuaikan dengan waktu alokasi waktu yang disediakan. Dari setiap setiap siklus terjadi perbaikan sesuai hasil refleksi. Pada siklus I, instrumen yang digunakan untuk menguji peserta didik terlalu banyak dan sulit untuk dijawab. Hal ini disebabkan peserta didik belum terbiasa menggunakan bahasa latin, mengigatkan peserta didik berada pada masa peralihan dari Sekolah Dasar, sifat anak-anak terlihat sangat meonjol. Sehingga untuk siklus berikutnya disusun instrumen yang lebih sederhana.

Data hasil evaluasi peserta didik digunakan sebagai bahan analisis untuk mengetahui penggunaan bahan ajar yaitu materi ajar berbasis pendekatan SAVI, LKPD berbasis pendekatan SAVI dan RPP berbasis pendekatan SAVI terhadap peningkatan hasil belajar peserta didik. Hasil untuk keseluruhan data hasil evaluasi menunjukkan bahwa setiap siklus terjadi peningkatan nilai rata-rata kelas. Pada siklus I tidak ada satupun peserta didik yang tuntas atau yang memiliki nilai 70 sehingga secara klasikal $0 \%$. Sedangkan nilai rata-rata kelas yang diperoleh 25 .

Siklus II instrumen telah disederhanakan. Nilai rata-rata kelas peserta didik meningkat yaitu 52 dengan ketuntasan secara klasikal 42\%. Peningakatan jumlah peserta didik yang tuntas meningkat dari $0 \%$ menjadi $42 \%$. Hal ini terjadi karena motivasi, rasa ingin tahu serta perhatian peserta didik mulai terlihat.

Siklus III terjadi peningkatan nilai ratarata kelas peserta didik dari 52 menjadi 72 . Peserta didik yang tuntas secara klasikal juga terjadi peningkatan dari $42 \%$ menjadi $71 \%$ pada siklus III. Instrumen yang digunakan untuk menguji peserta didik lebih disederhanakan serta lebih dikenal dan berada di lingkungan peserta didik. Pertanyaan yang dikembangkan bersifat analisis hal ini menunjukkan adanya peningkatan kemampuan intelektual peserta didik, serta jawaban bervariasi sesuai dengan sudut pandang dan menggunakan bahasa yang cukup sederhana.

Hasil belajar peserta didik setiap siklus terjadi peningkatan seiring dengan aktivitas pendidik untuk melakukan perbaikan terhadap hasil refleksi yang ditemukan setiap siklus. Perbaikan dimaksud agar peserta didik dapat memperoleh pengalaman belajar yang akan mempengaruhi hasil belajar. Hal ini sesuai dengan pendapat slameto (1988) yang menyatakan faktor psikologis dapat menunjang keberhasilan belajar yang meliputi intelegensi, perhatian, kemauan, bakat, motif yang kuat, kematangan belajar, dan kesiapan belajar dari peserta didik.

\section{Kesimpulan}

Berdasarkan hasil penelitian dapat ditarik kesimpulan bahwa penggunaan bahan 
ajar IPA berbasis pendekatan SAVI dapat meningkatkan hasil belajar peserta didik SMP N3 Mataram pada materi tingkat organisasi kehidupan.

\section{Daftar Pustaka}

Abdul Rasid, J., \& Hasmah, I. (2013). Pelaksanaan pembelajaran menyeronokkan dalam pengajaran dan pembelajaran bahasa Melayu (the implementation fun learning in teaching and learning malay language). JPBMMalay Language Education Journal MyLEJ, 3(2), 49-63. https://doi.org/10.1016/j.cccn.2005.06.01 8

Idaramatasia. (2015). Jurnal Pendidikan Fisika Universitas Muhammadiyah Makassar Penerapan Model Pembelajaran Generatif Untuk Meningkatkan. 4(1), 89-105.

Khoiruddin, M. A. (2017). Pendekatan Psikologi Dalam Studi Islam. Journal AnNafs: Kajian Penelitian Psikologi, 2(1), 1-17. https://doi.org/10.33367/psi.v2i1.343

Marpaung, J. (2016). Pengaruh Gaya Belajar Terhadap Prestasi Belajar Siswa. KOPASTA: Jurnal Program Studi Bimbingan Konseling, 2(2), 13-17. https://doi.org/10.33373/kop.v2i2.302

Munandar, H., Yusrizal, Y., \& Mustanir, M. (2015). Pengembangan Lembar Kerja Peserta Didik (Lkpd) Berorientasi Nilai Islami Pada Materi Hidrolisis Garam. Jurnal Pendidikan Sains Indonesia, 3(1), 2737.

stefany, evy maya. (2016). Model Pembelajaran Somatis, Auditori, Visual Dan Intelektual (SAVI): Implementasi Pada Mata Pelajaran Teknologi Informasi Dan Komunikasi (TIK) Di SMP. Edutic Scientific Journal of Informatics Education, 1(2), $1-7$. https://doi.org/10.21107/EDUTIC.V1I2. 1542

Widayanti, F. D. (2013). Pentingnya Mengetahui Gaya Belajar Siswa Dalam
Kegiatan Pembelajaran Di Kelas. Erudio Journal of Educational Innovation, 2(1). https://doi.org/10.18551/erudio.2-1.2

Winanto, A., \& Makahube, D. (2016). Implementasi Strategi Pembelajaran Inkuiri Untuk Meningkatkan Motivasi Dan Hasil Belajar IPA Siswa Kelas 5 SD Negeri Kutowinangun 11 Kota Salatiga. Scholaria: Jurnal Pendidikan Dan Kebudayaan, 6(2), 119. https:// doi.org/10.24246/j.scholaria.2016 .v6.i2.p119-138

Zein, M. (2016). Peran guru dalam pengembangan pembelajaran. Journal UIN- Alauddin, V(2), 274-285. https://doi.org/10.24252/ip.v5i2.3480 